\title{
Spinoza in His Time: The 17th-Century Religious Context
}

\author{
Joke Spaans
}

check for

updates

Citation: Spaans, J. Spinoza in His Time: The 17th-Century Religious Context. Philosophies 2021, 6, 27. https://doi.org/10.3390/

philosophies6020027

Academic Editors: Henri Krop and Pooyan Tamimi Arab

Received: 20 February 2021

Accepted: 26 March 2021

Published: 1 April 2021

Publisher's Note: MDPI stays neutral with regard to jurisdictional claims in published maps and institutional affiliations.

Copyright: (C) 2021 by the author. Licensee MDPI, Basel, Switzerland. This article is an open access article distributed under the terms and conditions of the Creative Commons Attribution (CC BY) license (https:/ / creativecommons.org/licenses/by/ $4.0 /)$.
Department of Philosophy and Religious Studies, Utrecht University, Janskerkhof 13-13a, 3512 BL Utrecht, The Netherlands; j.w.spaans@uu.nl

\begin{abstract}
In one of the last paragraphs of his Tractatus theologico-politicus (1670), Spinoza extolls the harmony between people of a diversity of faiths, maintained by the magistracy of Amsterdam. However, he also seems apprehensive about the possibility of the return of chaos, such as during the Arminian Controversies in the Dutch Republic in the 1610s and the English Civil War in the 1640s and 1650s. The so-called Wolzogen affair in 1668 probably rattled him. Spinoza's fears would, however, prove groundless. Theological controversy in the public church was often fierce and bitter, but did not threaten the integrity of the State after 1619. Political and ecclesiastical authorities supported discussions and debate in which a new theological consensus could be hammered out. From the examples of Petrus de Witte's Wederlegginge der Sociniaensche Dwaelingen and Romeyn de Hooghe's Hieroglyphica, I will argue that such freedom was not limited to the universities, under the aegis of academic freedom, but that Spinoza's call for free research and open debate was in fact everyday reality.
\end{abstract}

Keywords: Spinoza; Petrus de Witte; Romeyn de Hooghe

\section{Introduction}

In Spinoza's lifetime, the Dutch Republic rose to an impressive peak of power and wealth. Wartime conditions suited the ill-assorted handful of provinces. They never stopped trade-on the contrary, the unsuccessful attempts of the Spanish enemy to block expansion of existing shipping routes towards the Far East and the New World, where exotic spices came from and mountains of gold were rumoured to exist, provoked an armed response that won the Dutch a global emporium. Together with the manufacture of quality goods, the cultivation of industrial crops and efficient dairy farming at home, as well as piracy on the high seas, this created a wealthy elite of merchants and entrepreneurs as well as a thriving artisanal class. Strong social networks in cities as well as in rural areas buffered the shocks of personal misfortune due to sickness, too many young mouths to feed, or old age, and this in turn fostered a resilient workforce. The booming Dutch economy absorbed a massive immigration of labour migrants, both skilled and casual, and religious refugees from all over Europe, almost effortlessly.

Inevitably, fortune did not smile equally upon all, and the astounding military and economic successes had their victims. Yet, despite its darker sides, the designation 'Golden Age' fits the Dutch 17 th century [1,2]. ${ }^{1}$ Prosperity manifested itself in a thriving market for luxury goods, art and books. Rivalry between the seven provinces resulted in no fewer than five full-fledged universities and ten Illustrious Schools, testifying to a lively intellectual culture as well. The academic climate was highly competitive and internationally oriented [3]. Knowledge production spilled over from the Latinate academies into a much broader milieu of skilled artisans, inventors, artists and writers. In the absence of censorship, except on publications that were considered outright seditious, blasphemous or slanderous, they found information on every conceivable subject in the thriving Dutch book market, also in the vernacular, and contributed to knowledge production in their

\footnotetext{
1 The way Prak in 2020 rewrote his earlier book reflects the recent discussion on the term 'Golden Age' in the Netherlands.
} 
turn $[4,5]$. Although the Dutch Reformed church was the public church of the Republic, and the many and various religious dissenters faced restrictions in their freedom of public worship and access to public office, they were excluded neither from the economy, nor from intellectual culture and debate. Spinoza himself is an eloquent example of this. In what follows, we will look at the context of Spinoza's thought: the religious diversity, the theological controversies, and the general culture of free debate in the Dutch Republic of his days.

\section{Religious Diversity}

In one of the last paragraphs of his Tractatus theologico-politicus, Spinoza extolls the harmony between people of a diversity of faiths, maintained by the magistracy of Amsterdam. In this excellent city, he writes, 'all kinds of people, belonging to every nation and professing every faith, live together in perfect unity' [6] (chapter 20, § 15). An attempt to visualise this diversity yields something like Figure 1 . What you see is a contemporary map of Amsterdam. Each of the dots represents a house of prayer that was in use during the 17th century, and the dots are colour coded for the various Christian confessions and the Jews [7] (pp. 412-413).

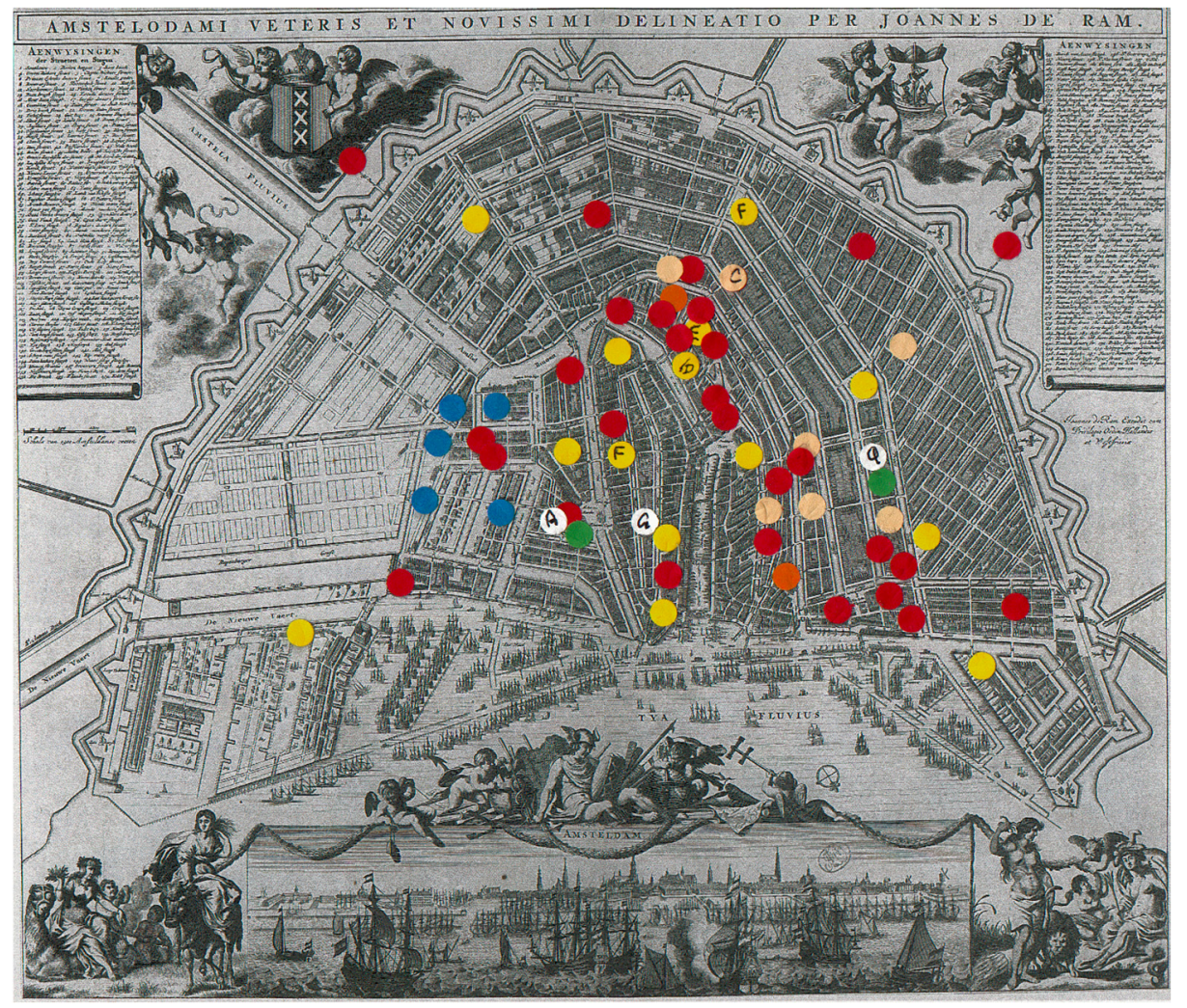

Figure 1. Map of Amsterdam, designed by Johannes de Ram, ca. 1683, Rijksmuseum Amsterdam sign. RP-P-AO-20-46, overlaid with an impression of the locations of churches and synagogues.

What strikes the eye is that the Reformed Church, as the result of an extensive building programme, had the use of old and new church buildings evenly spread throughout the old city centre as well as the recently built neighbourhoods around it: the yellow dots. Reformed immigrants from Francophone, Anglophone or German speaking lands could attend services in their own designated buildings (yellow dots marked F, E, D respectively). Yet the Reformed churches were far outnumbered by the Catholic 'hidden churches': the red dots. Various other religious groups were numerous enough to have several places of worship at their disposal: the relatively prosperous Mennonites (salmon dots) in the prestigious western half of the city, the on average poorer Jews (blue) at the eastern side, 
the numerous Lutherans (orange dots) in the centre and near the waterfront where many of them found work. At a glance, one can see that Reformation and Revolt had not turned the Dutch Republic into a Calvinist nation.

Amsterdam, the hub of trade and finance, and the largest of the Dutch cities, may have been religiously the most diverse, but when we broaden our view to the country as a whole we can see how unsuccessful the Reformed church had been in winning hearts and minds of the Dutch and how diversity reigned all over. Brabant and Limburg had remained overwhelmingly Catholic. But also in numerous villages in the rural heart of Zuid-Holland, a Reformed minister had to make a congregation work with only a handful of parishioners among a solidly Catholic local population. Similar instances of strong Catholic presence could be found in Utrecht, in Twente (Overijssel) and the southeast corner of Friesland. In Graft in Noord-Holland, Mennonites formed a local majority, and Mennonites of several denominations were spread all over Groningen and Friesland. Rotterdam was almost as diverse as was Amsterdam, but here the Remonstrants had an exceptional stronghold.

The religious fragmentation of the Dutch population was compounded by the influx of immigrants, refugees and wanderers from practically everywhere. Foreign merchants settled in the port cities, diplomats and their retinues around the courts of the stadholders in Den Haag and Leeuwarden. Foreign students visited the academies. Soldiers and sailors of many nationalities served the Dutch army, the navy and the merchant fleet. Refugees and adventurers of all stripes built their fortunes here or held on to a more precarious existence on the margins of the industriousness and prosperity of the Dutch Republic in its Golden Age. Among these immigrants, and especially among the refugees, many were Reformed, but perhaps even more belonged to different faiths. Amsterdam, to stay with that example, harboured numerous immigrant churches, with as the most visible the Lutherans and the Jews. They were considered nationes: communities of resident foreigners who benefited the city with their trade, and enjoyed all kinds of privileges in return. Among these privileges was the right to public worship, and to build monumental public churches and synagogues. In the 18th century, for the same reasons, the Armenians would be granted full religious freedom, in a smaller church, but one that by the decoration on its façade was immediately recognisable as belonging to Eastern Christianity (the white dot marked A on the map). These privileges infringed upon the Reformed church's monopoly on public worship. Catholics, Mennonites, Remonstrants (green dots), Greek Orthodox and Quakers (white dots marked $\mathrm{G}$ and Q) and several smaller groups had to make do with hidden churches, discreetly disguised as ordinary residences or warehouses [7-9].

In Spinoza's paean to Amsterdam the different religious groups together made up one harmonious mix. But he did not write his Tractatus in order to sing the praise of Dutch tolerance. Rather, he intended to warn the political authorities that this harmony was under threat, and that they should do their utmost to maintain it. He does not specify a concrete reason for his fears, but the drift of his argument is that religion was a hazard, more specifically its ministers, who had the ear of the common people. Most dangerous of all were occasions where ministers wanted to impose a contested religious regime, and found support with politicians. Here, Spinoza saw a recipe for a disturbance of public order, and eventually for civil war.

The ministers of the Dutch Reformed church, indeed, have something of a reputation for engaging in endless theological controversies and for theocratic ambitions. But when one takes a good look at the constitution of the public church, and especially when one compares it to the ecclesiastical establishments in other European countries at the time, the public church was not all that powerful. In England, for instance, the Anglican Church was 'by law established': her bishops had (and still have) session in the House of Lords. Here, as well as in Catholic and Lutheran countries, in the Protestant Swiss cantons and German principalities, ecclesiastical courts held jurisdiction over infractions on laws that were 'mixed', that is both secular and ecclesiastical (such as for instance family law and public morality), and could impose fines and prison sentences-but not in the Dutch Republic. Here, the public church was protected by the State, but it was not a 'person in 
law'. It was financially completely dependent on the political authorities. For ecclesiastical appointments and for the sessions of classes and synods, political approval had to be asked, and the decisions of synods were invalid without ratification by the States of the provinces. There was no 'mixed' jurisdiction here-the civil and criminal courts were fully competent in all legal cases [10]. Theologians could and did offer advice, and sometimes it was heeded, but not necessarily so. The authorities kept their hands free.

Even so, in the past, matters had spun dangerously out of hand. During the Arminian Controversies of the 1610s, theological and political conflicts had become inextricably entangled. In the church, Remonstrants had opposed Counter-Remonstrants; and in politics, the stadholder had faced the powerful States of Holland and their grand pensionary. Civil war had been averted only by a coup de main of Maurits van Nassau. He had Johan van Oldenbarnevelt condemned for high treason and beheaded. He ordered the States General to convene a national synod. This international ecclesiastical gathering, held in Dordrecht in 1618 and 1619, decided upon the contentious theological points. An after-session exclusively for the representatives of the Dutch churches formulated a new church ordinance that was ratified by the States of the provinces only after everything that smacked of ecclesiastical autonomy had been expunged-and in Friesland, was rejected entirely [11]; [12] (vol. I, pp. 268-275).

As frightening as the Arminian Controversies had been, the ultimate horror scenario was the English Civil War. It was fresher in everyone's memory, and matters had escalated even more spectacularly. Here, also, ecclesiastical factions had been at loggerheads: the High-Church wing of the Church of England against the English Puritans and the Scottish Presbyterians. Parliament deposed, judged and beheaded the anointed king, ruling by the grace of God-to the consternation of all of Christendom. In politics and in religion, for years England was the scene of unprecedented chaos, until in 1660 both the monarchy and the established church were restored [13]. In his Tractatus, Spinoza suggested that anarchy could overwhelm the Republic again, if the authorities would not allow everybody 'to think as he pleased, and to say what he thought'. Such freedom, Spinoza claimed, could not harm the State, but on the contrary, would strengthen it, whereas compulsion and censorship in religious matters would foment discontent.

\section{Theological Controversy}

The decades preceding the appearance of the Tractatus theologico-politicus were indeed again marked by theological controversies entangled with political strife. The background to these controversies is well known: the work of Descartes met with an eager response, but also provoked sharp protests. It did not only divide contemporary philosophers, but above all caused havoc in the theological faculties. Once the work of Descartes appeared in Dutch translation, controversy spread also outside academic circles, fanned by acrimonious pamphlets. Yet the universities bore the brunt of the conflict. After a first round of difficulties at the university of Utrecht in the 1640s, in 1656, in an attempt to calm the waters, curators of the university of Leiden banned the teaching of and disputations about Cartesian philosophy from the theological faculties. Students loudly protested. That same year the synod of Zuid-Holland deliberated on the unrest at the provincial university. As was customary, acting members of the States of Holland, the so-called commissarissen-politiek, attended the synod. These commissioners were not just passive observers: they could and did enter into the deliberations of the synod, backed by the full weight of their high office-as I remarked before, the Reformed church was by no means autonomous. With their input, the synod drafted a Resolutie tot vrede der kerk (Resolution towards the peace of the church), which was then duly promulgated by the States of Holland. Theologians and philosophers were commanded to keep to their respective disciplinary fields. When and where these overlapped, as was the case with Cartesianism, they had to hammer out a peaceful compromise [14,15]; [16] (vol. I, pp. 306-311); [17] (vol. III, pp. 517-519 and vol. IV, pp. 35-42); [18] (vol. III, pp. 111-112, 55*-58*). 
Thus, without taking a stance themselves, synod and States attempted to quell disorder while maintaining academic freedom. Peace was not restored overnight. Abraham Heidanus and Johannes Cocceius, the leading theologians at the university of Leiden, made advanced students defend Cartesian theses in public academic disputations. In this way, they probed the boundaries of what was acceptable. Several times these experiments erupted into violent riot. It had always been part of accepted academic culture that students who strongly disagreed with speakers' ideas would prevent them from being heard, making an unholy din banging on the furniture with their fists and stamping their feet on the wooden floors. This time, however, the audience in the stately academic auditorium also pelted the professors presiding over the disputation and the students who had ventilated offending notions with garbage, so that the sheriff had to rescue the beleaguered academics and escort them home [19] (pp. 384-386, 426-427); [20] (pp. 42-43); [21] (pp. 80-89); [22] (pp. 212-214).

In 1668, riots hit the streets-this time not in Leiden but in Middelburg. Here, the fiery puritanical preacher Jean de Labadie was minister to the Walloon congregation. He had accused a fellow Walloon minister, Louis Wolzogen, a Cartesian, of the most heinous heresies-wrongly so, in the eyes of the Walloon synod. The synod demanded apologies from De Labadie, but he refused. De Labadie's adherents vented their displeasure with this assault on their minister's honour in the streets of Middelburg. The magistracy had to send in law enforcement to restore order. When the synod thereupon decided that De Labadie should be deposed for recalcitrance, the States of Zeeland and even the Staten-Generaal had to throw in their weight to prevent further mayhem [23]; [24] (pp. 79-103).

During the years between the 1656 resolution towards the peace of the church in the States of Holland and the riots in Middelburg in 1668, coalitions had formed between prominent Dutch Reformed theologians. One faction was made up of men who fiercely rejected the new philosophy, and who often sympathised with the views of English Puritans. De Labadie counted upon the strength of this group, and gambled that with their backing he could defy the Walloon synod. On the other side a more diffuse coalition had formed of men who were eager to experiment with new philosophical concepts and innovative biblical exegesis in order to modernise Reformed theology, and bring it up to date with current scholarly trends. Spinoza seems to have regarded the escalation of violence in these years - from the normal exuberance of students, to threats of bodily harm in the Leiden auditorium, to fisticuffs on the streets of Middelburg, and eventually the involvement of the highest level of the political authorities with what was essentially a theological controversy - as the harbingers of a new round of civil strife on the model of the Arminian Controversies or even the English Civil War.

At that moment, the oppositional camps were as yet ideologically ill defined-personal animosities played a substantial role. Yet, in the 1650s and 1660s we see the contours take shape of what in the 1670s and 1680s would become known as the Voetian and Cocceian factions. Polemical exchanges and backbiting between them seriously disrupted the Dutch Reformed church, in several waves, between 1672 and 1694. In the latter year, the States of Holland promulgated a new resolution towards the peace of the church. This time the States of the other provinces copied it, and this effectively put an end to this conflict [25]. In the 18th century, even after the battle axes had long ago been buried, people would shudder at the recollection of the fierceness of the ecclesiastical troubles. The Voetian and Cocceian controversies overshadow the historiography of the period until the present day. Yet, the integrity of the State was never in danger, and no blood was shed.

\section{General Debating Culture and Libertas Philosophandi}

Spinoza's fears thus proved groundless. They were groundless, because both State and Church already practiced what Spinoza preached: freedom of research and debate, libertas philosophandi-also, and perhaps even especially, regarding theological claims [8] (pp. 218-224). This was already visible in the resolution towards the peace of the church in 1656, which did not aim at silencing the debate over Cartesianism, but first of all at keeping 
it civilised. In two examples, I want to demonstrate that this was not merely an incident, but rather the official policy of the authorities in Church as well as State, and a deeply rooted sentiment within the wider intellectual culture of the Dutch Republic, also outside the academies.

My first example is the response to Socinianism. The Socinians, or, as they were also called, the Polish Brethren, were the descendants and spiritual heirs of antitrinitarians who, in the 16th century, had fled Italy for the then very tolerant Poland. They were strict monotheists, who rejected the Trinity and the divinity of Christ as one Person of one tri-une God, and were considered dangerous heretics by all other Christian confessions. In Poland, however, Socinianism spread and was given freedom of worship as one of the four publicly admitted confessions, alongside Catholicism, Lutheranism and Calvinism. In Rakow, Socinians established their own academy. Socinian theologians were admired and feared for their skill in theological controversy. Through correspondence and occasional visits abroad, they built an international network of sympathisers, also within the Dutch Republic. Those contacts proved very valuable when Counter-Reformation Catholicism gained the upper hand in Poland, and the Socinians were forced into exile.

Whether many Polish Brethren came to the Dutch Republic remains unknown. They did not establish Socinian congregations or any visible organisation here. However, their fanning out over Europe was already considered a dangerous threat. Around the middle of the 17th century, practically every Dutch theologian worth his salt wrote a learned Latin refutation of Socinianism. They were considered the ultimate enemies of the Reformed church, as sharp debaters and excellent defenders of a pernicious, but highly cogent, and therefore attractive and convincing doctrine [26]. As far as I know, it has never been done, but I would not be surprised if comparative research would show that at that point the Dutch Reformed were more alarmed about Socinianism than they would be about Spinozism a few decades later.

Now one would expect the Reformed church to do everything in its power to suppress Socinianism. At a later moment, the church indeed requested a ban on the public sale of the Bibliotheca Fratrum Polonorum, the authoritative collection of the books of the most prominent Socinian theologians, printed in nine hefty folio volumes in Amsterdam and Leiden between 1665 and 1692. But the Reformed church did not attempt to protect its members by shielding them from Socinian ideas, quite the contrary even. In 1655, the impeccably orthodox Petrus de Witte, Reformed minister in Delft and later in Leiden, published a Wederlegginge der Sociniaensche Dwaelingen (Refutation of Socinian Errors) in the vernacular and with full ecclesiastical approbation [27]. This book emphatically aimed at a broad lay audience. It was written in the form of questions and answers, like a textbook, or a catechism. It provides a detailed overview of Socinian doctrines. It liberally quotes the works of Socinian theologians by chapter and verse, and thus not only refutes them, but also offers an easy entry into their works. And the Wederlegginge sold very well: within seven years four editions appeared, each new one more extensive than the earlier ones.

Dutch Reformed readers were familiar with theological primers. This was the result of an intensive programme of catechism teaching. Not only schoolchildren and those who prepared for full membership had to know their catechism, the States of Holland urged the churches to catechise adults as well, in church and in their homes, in an effort to persuade wavering Catholics and others to join the public church. Leading theologians were developing methods for advanced catechetical training of confirmed church members, following the guidelines of the national synod of Dordrecht, and by the middle of the 17 th century this form of lifelong religious learning was becoming rather popular. By no means did all believers have the time or the inclination to join these lessons. Yet many a Reformed minister wrote a textbook in which, starting from the Heidelberg Catechism, Reformed doctrine was explained in great detail. Although more often than not these books were substantial tomes, they met with a lively demand. Authors vied for the attention of book buyers and readers, offering the reading public variety in style and presentation to choose from, some adding the lyrics for devotional songs, others enriching the lessons 
on the Catechism with titbits of biblical antiquities or church history. The most popular titles were reprinted repeatedly, often over a long period of time, suggesting considerable demand. Korte schets der godlyke waarheden (Short sketch of the divine truths) by the popular Amsterdam minister Johannes d'Outrein, despite its title a book of over 400 densely printed pages, saw over twenty editions between 1688 and the middle of the 18th century. In the wake of this catechetical 'campaign', a lively market emerged for translations of works of academic theology, originally published in Latin, and for scholarly theological books published immediately in the vernacular. It became a mark of an all-round education and urbanity to be theologically articulate, and to be able to follow, and even join, current debates [28,29].

People were encouraged not only to be knowledgeable about their own Reformed orthodoxy, but also about alternatives. Petrus de Witte of course impressed upon his readers that Socinianism was to be considered a soul-corrupting heresy, but he did not invoke his clerical authority. He first presented his readers with a solid crash course in Socinianism, before contrasting it with Reformed truths, in order to enable them to judge for themselves. Undoubtedly, theology students, who had to study theological controversies as part of their training, avidly read De Witte's book, as it was easier going than the Latin textbooks. But his Wederlegginge der Sociniaensche Dwaelingen reached a much wider audience. The Leiden University Library holds a copy in which one Allert Aryans van Worms has written his name on the flyleaf (Figure 2). ${ }^{2}$ On the next empty page, he made the note that he had sold Baertge Willems a poker and five fishes, for eight stuivers, and that he had given her a sixth fish for free. ${ }^{3}$ Apparently Allert was a fisherman or sold fish for a living. In another hand follows the name of the next owner, Dirck Maertens, and the way he had acquired it: he bought it from Allart Aryans 'with the fish, each fish a dubbeltje' (= two stuivers) (Figure 3). ${ }^{4}$ The nature of this transaction is not entirely clear. It may have been a betting game. Anyway, it had nothing of the academic or the ecclesiastical about it. Remarkably a book on Socinianism changed hands 'with the fish', and found readers way outside the world of scholars and their well-stocked libraries and bookshops.

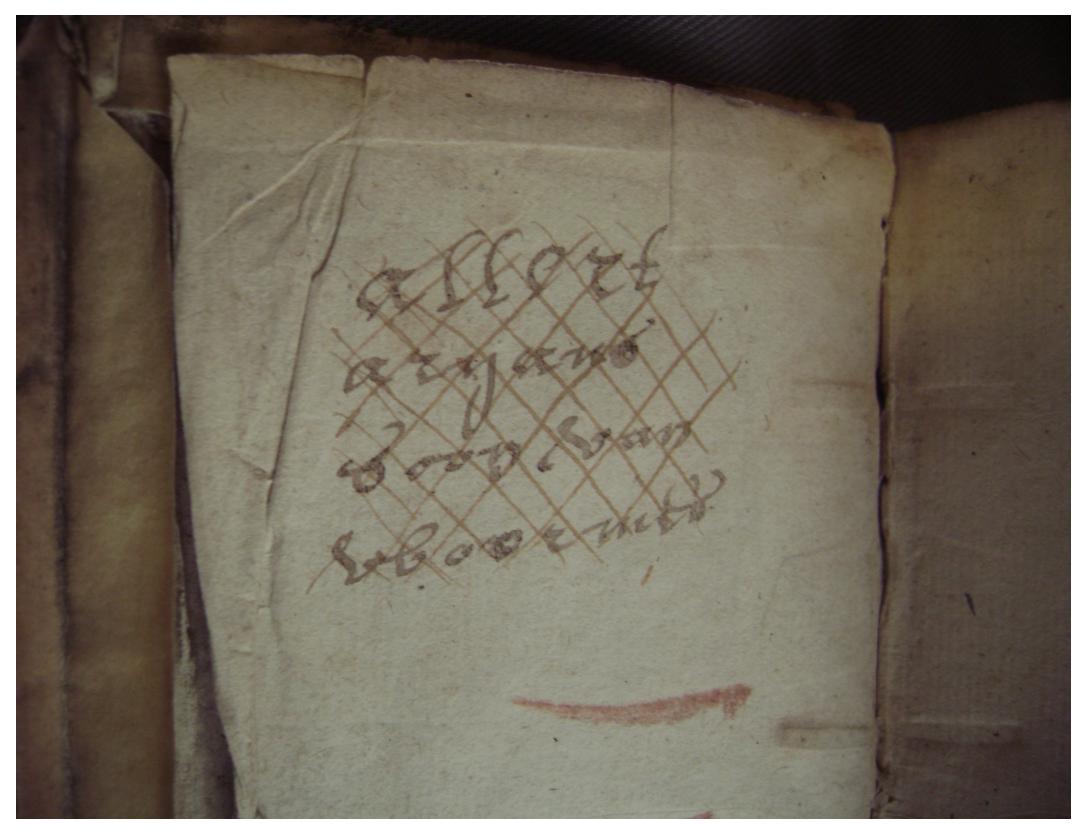

Figure 2. Owner's inscription in the first edition of De Witte's Wederlegginge, fly leaf, UB Leiden, shelf mark $55 \mathrm{H} 16$.

2 (loosely crossed out) 'allert aryans soon van Woormts'.

(loosely crossed out) 'aen Baertge Willems ver kocht een poock 5 visse vrij de 6.8 stuijver'.

'Dirck Maertensz hoort dit boeck toe heeft het gekocht op de vis yder vis een dubbeltie van allert arejans'. 


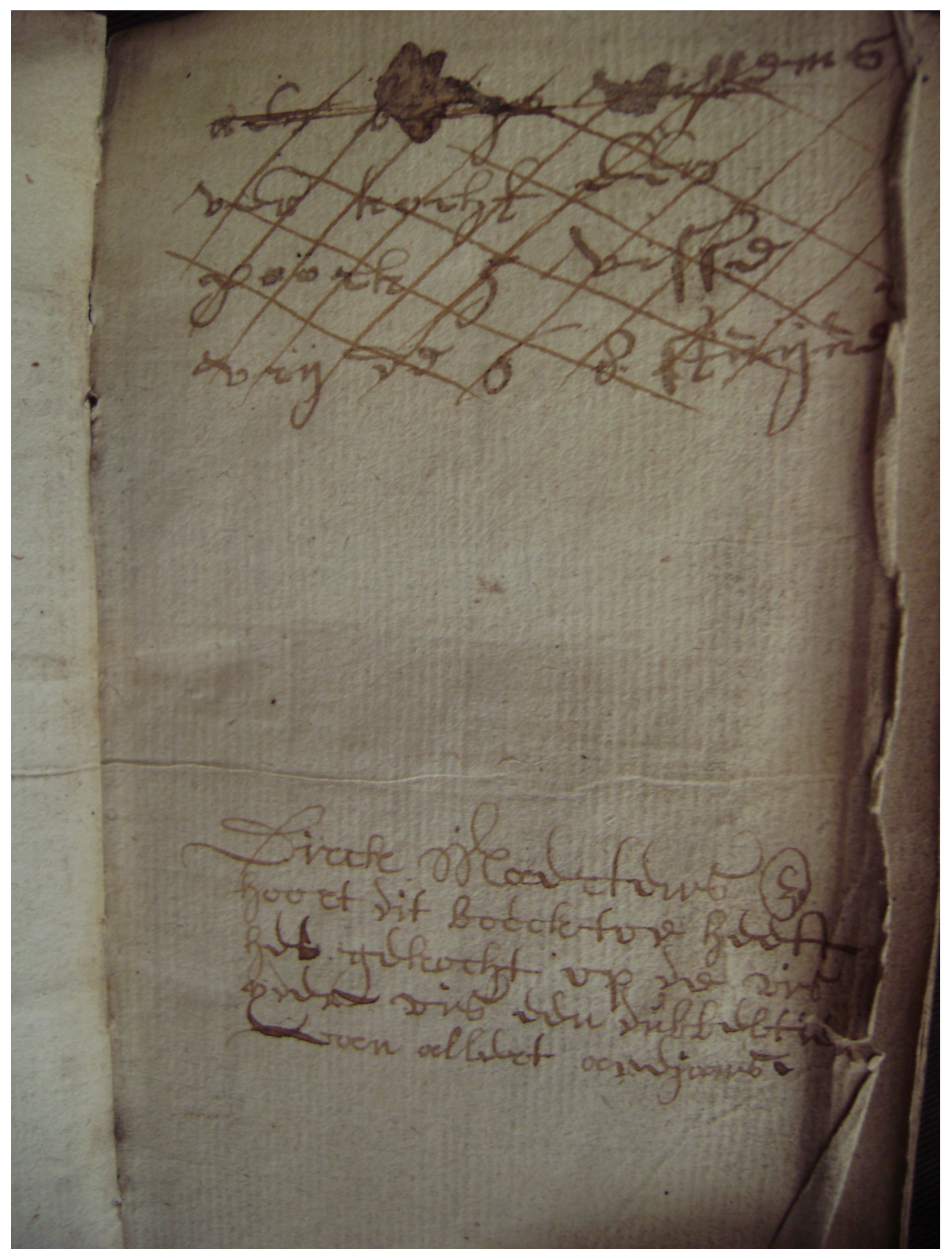

Figure 3. Reminder of a sale of fish on the next empty page of the same book, and new owner's inscription.

My second example is the depiction of the Peace of God's Church, designed by the then famous etcher Romeyn de Hooghe (Figure 4). It is one of 63 elaborate etchings in his Hieroglyphica of merkbeelden der oude volkeren (Hieroglyphica or Emblems of the Ancient Peoples), published posthumously in 1734. Near the end of his very successful, although not entirely uncontroversial career De Hooghe wrote two substantial and very innovative books: Spiegel van Staat (Mirror of the State, 1706-1707) on the structure of the Republic as one state, highly decentralised, as it was the product of a long historical process; and Hieroglyphica on the history of religion, as a process of decline and recent reformation. De Hooghe was first of all an artist, who produced what the market demanded, but in much of his work, and especially in these two books, he proves himself a voracious reader and a well-informed, perceptive observer of the time in which he lived. Much of his factual material on the past was copied from earlier works, most of the time without reference to his sources, as was not uncommon at the time. However, the argument he makes in both books eventually looks at the present and the promises it holds for a better future [30-32]. 


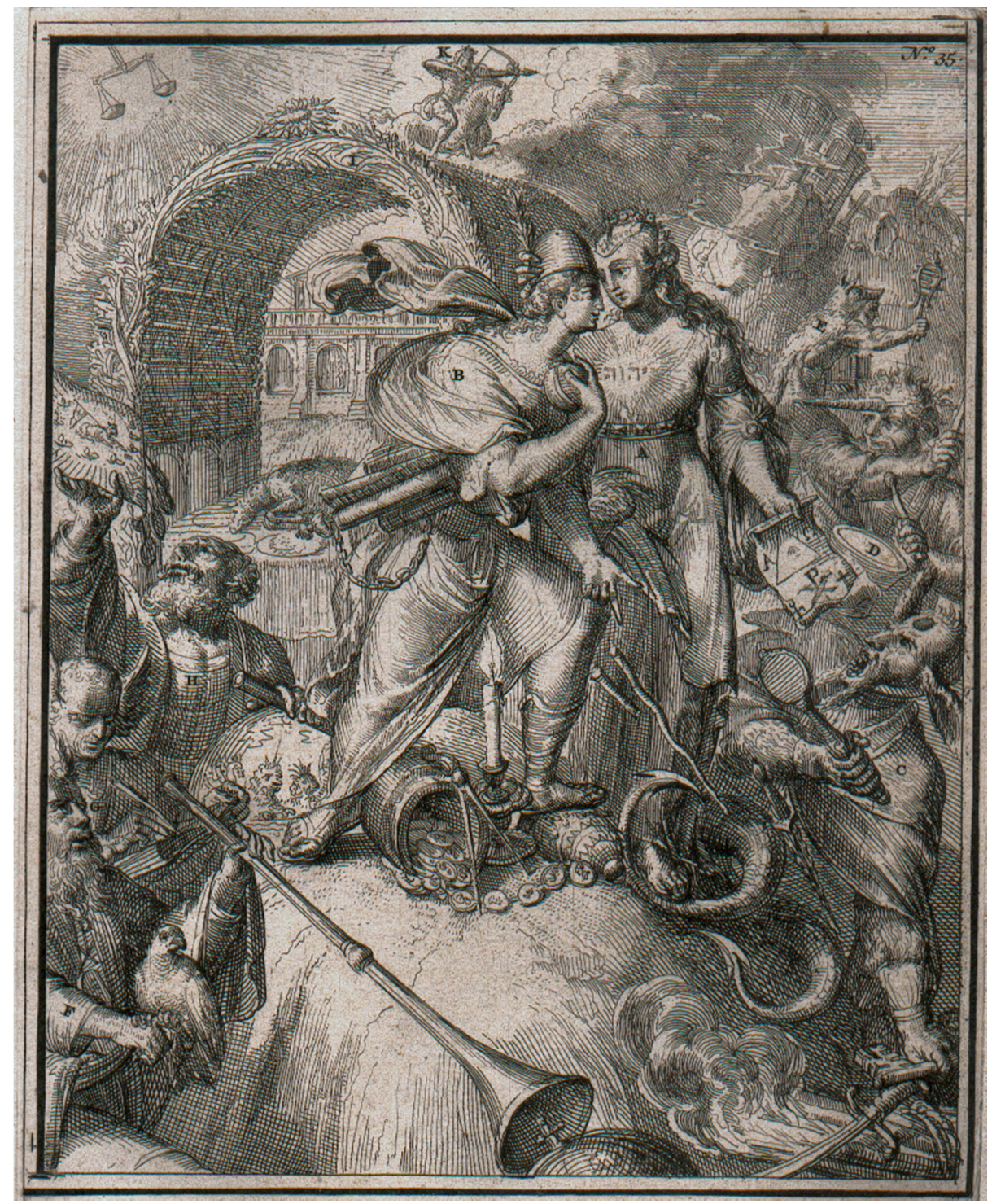

Figure 4. Plate 35, Van de Vrede van Gods Kerk (on the Peace of God's Church), in Romeyn de Hooghe, Hieroglyphica. Private collection.

For the study of early modern Dutch religion, the etchings in Hieroglyphica are a unique source. Besides the portraits of theologians and images of church buildings, we actually do not have much pictorial material to study [33] (pp. 22-27). I am struck time and again by the ways De Hooghe captured the then current discourse on religion in his images. Plate 35 in Hieroglyphica depicts the Peace of God's Church, very probably a reference to the only recently issued resolution towards the peace of the church [31] (pp. 326-333). The central figures in this etching are the Peaceful Church (A) and her industrious sister Free Inquiry (B), who also stands for the body of the faithful. The Peaceful Church, the true Bride of Christ, can be free of internal strife and schism because she allows her members a Christian freedom to search the divine mysteries contained in the Holy Scriptures. Free Inquiry wears the hat of liberty, and at her feet lie old coins and a set of compasses, symbols for the study of antiquity and scientific measurements. She tramples a tiara, the emblem of the Papacy.

The couple is flanked by images of good and evil. The enemies of the Peaceful Church and Free Enquiry are depicted on the right side of the image. First among them is the Papacy (C), in the shape of a bellowing tyrant who imposes his will by force. Donkeys' ears indicate his disrespect for learning, and he is surrounded by instruments of oppression: the 
schoolmasters' ferule, the sword, and the keys to heaven in his hands, the smoking faggot for the stakes on which heretics were burned at his feet. Behind him, we see false prophets. On the other side of the picture, De Hooghe placed a worthy missionary (F), trumpeting the Gospel to the world, inspired by the Holy Spirit (the flame of Pentecostal fire on his forehead), approaching the heathens not with force, but with sweet eloquence (the parrot on his hand). Behind him is a learned man (G), searching the Scriptures, exposing falsehoods and establishing truths. His head is winged to denote his quick intellect. The third figure on this side is a wise old man, his eyes on the saving truths of biblical revelation, his hand resting on a globe bearing the images of the prophets, holding a telescope, the instrument of far-seeing.

In the chronology of Hieroglyphica, plate 35 offers an idealised image of the early medieval church, when the Papacy rose to power, to become what the Reformers would reject as the Antichrist, but also when bible studies and theological learning flowered in monasteries and Christian missionaries successfully converted the European heathens (figure $\mathrm{K}$, an armed knight, illuminated by the sun of justice, chasing away the darkness of heathen superstitions). Yet the image is suffused with references to his own time. A large part of the background to Peaceful Church and Free Inquiry is taken up by an enormous booth of green boughs, such as were in use for the Jewish Feast of Tabernacles. This festival played an important part in the eschatology of Johannes Cocceius, whose 'prophetic' theology was at the peak of its popularity in the first decade of the 18th century, when De Hooghe created his Hieroglyphica. For Cocceius, it was a prefiguration of a time in the future, when the church as an institution would become obsolete: when true doctrine had conquered and unified the peoples of the world, and universal peace reigned [34] (§ 636-650).

In Hieroglyphica, De Hooghe looks back upon a period in which theologians had explored Cartesian mathematics, the many religions of the peoples overseas, and above all the text of the Bible, against the background of antiquarian and philological studies. This process of exploration had produced clashes like the Voetian and Cocceian controversies, and had fed a climate of libertinism that rejected biblical revelation [35]. More important in the long run, however, was that it modernised Reformed theology, made it compatible to the scholarly discourses of its time. It had done so by tightening the focus of theology on the conversion and spiritual regeneration of the individual believer, and abandoning the all-encompassing claims of the confessional churches to embody the truth in all areas of life, in science and scholarship, in government and social discipline, as well as in religion. As has been argued before, the grip of the public church on politics and public morality was already relatively weak in the Dutch Republic. If we regard De Hooghe as a mouthpiece for public opinion among the intellectual elite, as I think we should, his Hieroglyphica can be taken as testimony to the dominance of libertas philosophandi in Dutch public discourse, in the universities as well as in the public church and in polite society as a whole [32] (pp. 133-157).

\section{Conclusions}

Spinoza lived in a country marked by religious diversity and a lively culture of discussion. Adherents of a wide variety of faiths and libertines who had abandoned religion lived side by side, and public debate encompassed religion, also in a comparative perspective. Differences of opinion were negotiated in public debate, also when these differences concerned religion: in academic disputations, in pamphlets, undoubtedly during the advanced catechism classes, in artistic expression, and apparently even among fishermen and their customers. Debate could be fierce. Controversies could span years and even decades. But with the Arminian Controversies and the English Civil War within living memory, the political authorities refrained from intervention and backing one faction over the other. Like Spinoza, they were all too aware how that could lead to civil discord.

The freedom of debate was not unlimited, but compared to the situation in other early modern confessional states, its boundaries were very wide. The public church could not 
impose its orthodoxy, even had she wanted to. Instead she educated everybody willing to hear, on a voluntary basis, on her own orthodoxy, but also on those of others. Inevitably, confrontation and comparison led to negotiation, and gradually the character of the church and of its doctrine changed. What had counted as orthodoxy in the 16th century no longer satisfied in the seventeenth, when new knowledge led to new questions that demanded new answers. The Cartesian and Cocceian 'novelties' that provoked such heated controversy, were outdated in the eighteenth. Much of what had been unacceptable in the 17th century was eventually absorbed by a new Reformed orthodoxy, after it had been examined from all sides, measured and weighed in public discussion. Spinoza engaged himself in that debate, influenced it and was influenced by it in turn, and became the object of debate himself. It was his intellectual home.

Funding: This research was funded by Nederlandse Organisatie voor Wetenschappelijk Onderzoek, grant number 360-25-110.

Institutional Review Board Statement: Not applicable.

Informed Consent Statement: Not applicable.

Data Availability Statement: Not applicable.

Conflicts of Interest: The author declares no conflict of interest.

\section{References}

1. Prak, M. Gouden Eeuw. Het Raadsel van de Republiek; Sun: Nijmegen, The Netherlands, 2002.

2. Prak, M. Nederlands Gouden Eeuw. Vrijheid en Geldingsdrang; Prometheus: Amsterdam, The Netherlands, 2020.

3. van Miert, D. The Reformed Church and Academic Education in the Dutch Republic (1575-1686). In Frühneuzeitliche Bildingsgeschichte der Reformierten in konfessionsvergleichender Perspektive. Schulwesen, Lesekultur und Wissenschaft; Schilling, H., Ehrenpreis, S., Eds.; Duncker \& Humblot: Berlin, Germany, 2007; pp. 75-96.

4. Weekhout, I. Boekencensuur in de Noordelijke Nederlanden. Een Verkennend Onderzoek naar de Vrijheid van Drukpers in de Zeventiende eeuw; Sdu: The Hague, The Netherlands, 1998.

5. Pettegree, A.; der Weduwen, A. De Boekhandel van de Wereld. Drukkers, Boekverkopers en Lezers in de Gouden Eeuw; Atlas/Contact: Amsterdam, The Netherlands, 2019.

6. Spinoza, B. Tractatus Theologico-Politicus; Henricus Künrath: Hamburg, Germany, 1670.

7. Spaans, J. Stad van vele geloven 1578-1795. In Geschiedenis van Amsterdam; Marijke Carasso Kok, M., Ed.; Volume II/1: Centrum van de wereld 1578-1650; SUN: Amsterdam, The Netherlands, 2004; pp. 384-467.

8. Frijhoff, W.; Spies, M. 1650. Bevochten Eendracht: Nederlandse Cultuur in Europese Context; Sdu Uitgevers: The Hague, The Netherlands, 1999; pp. 351-432.

9. Knippenberg, H. De Religieuze Kaart van Nederland. Omvang en Geografische Spreiding van de Godsdienstige Gezindten Vanaf de Reformatie tot Heden; Van Gorcum: Assen/Maastricht, The Netherlands, 1992.

10. Spaans, J. Consistorial discipline in the later seventeenth and eighteenth centuries. An endgame? In Judging Faith, Punishing Sin: Inquisitions and Consistories in the Early Modern World; Charles Parker, C., Starr-Lebeau, G., Eds.; Cambridge University Press: Cambridge, UK, 2015; pp. 306-316.

11. Van Deursen, A.T. Bavianen en Slijkgeuzen. Kerk en Kerkvolk ten Tijde van Maurits en Oldenbarnevelt; Van Gorkum: Assen, The Netherlands, 1974.

12. De Visser, J.T. Kerk en Staat; A.W. Sijthoff Uitgeversmaatschappij: Leiden, The Netherlands, $1926-1927$.

13. Hill, C. The World Turned Upside Down. Radical Ideas during the English Revolution; Temple Smith: London, UK, 1972.

14. Verbeek, T. Descartes and the Dutch. Early Reactions to Cartesian Philosophy, 1637-1650; Southern Illinois University Press: Carbondale, IL, USA; Edwardsville, IL, USA, 1992.

15. Van Wiep, B. From Stevin to Spinoza. An Essay on Philosophy in the Seventeenth-Century Dutch Republic; Brill: Leiden, The Netherlands, 2001.

16. Kerkelyk Plakaat-Boek, Behelzende de Plakaaten, Ordonnantien, en Resolutien over de Kerkelyke Zaken; Wiltens, N., Paulus Scheltens, P., Eds.; Paulus and Isaac Scheltus a.o.: The Hague, The Netherlands, 1722-1807.

17. Acta der Particuliere Synode van Zuid-Holland; Knuttel, W.P.C., Ed.; Martinus Nijhoff: The Hague, The Netherlands, $1908-1916$.

18. Bronnen tot de Geschiedenis der Leidsche Universiteit; Molhuysen, P.C., Ed.; Martinus Nijhoff: The Hague, The Netherlands, 1913-1924.

19. Otterspeer, W. Groepsportret met Dame; Bert Bakker: Amsterdam, The Netherlands, 2000-2005.

20. Hofmeyr, J. Hoornbeeck as polemikus; Kok: Kampen, The Netherlands, 1975.

21. Cramer, J.A. Abraham Heidanus en zijn Cartesianisme; J. van Druten: Utrecht, The Netherlands, 1889.

22. Vermij, R. Ruzie over de antichrist. Cornelis Uythage (ca. 1640-1686) als geleerde querulant. Studium 2014, 7, 209-222. [CrossRef] 
23. Bezemer, C. Wolzogen, Ludovicus. In Biografisch Lexicon voor de Geschiedenis van het Nederlands Protestantisme; J.H. Kok: Kampen, The Netherlands, 1978; Volume 1, pp. 435-436.

24. Schneemelcher, W. Mathias Nethenus. Leben und Werk. Ph.D. Thesis, University of Bochum, Bochum, Germany, 1972.

25. Een Richtingenstrijd in de Gereformeerde Kerk. Voetianen en Coccejanen 1650-1750; Broeyer, F.M.G., van der Wall, E.G.E., Eds.; Boekencentrum: Zoetermeer, The Netherlands, 1994.

26. Spaans, J. Réfuter le socinianisme dans la république des Pays-Bas. In Le Protestant et l'Hétérodoxe. Entre Églises et États (XVIe-XVIII Siècles); Recous, N., Krumenacker, Y., Eds.; Classiques Garnier: Paris, France, 2019; pp. 93-113.

27. De Witte, P. Wederlegginge der Sociniaensche Dwalingen, in Forme van Catechizatie; Jan Pietersz Waalpot: Delft, The Netherlands, 1655.

28. Touber, J. The Culture of Catechesis and Lay Theology. Lay Engagement with the Bible in the Dutch Reformed Church, 1640-1710. Church Hist. Relig. Cult. 2018, 98, 31-55. [CrossRef]

29. Spaans, J. Between the Catechism and the Microscope: The World of Johannes Duijkerius. In Enlightened Religion. From Confessional Churches to Polite Piety in the Dutch Republic; Spaans, J., Touber, J., Eds.; Brill: Leiden, The Netherlands, 2019; pp. 316-345.

30. Van Nierop, H. The Life of Romeyn de Hooghe 1645-1708: Prints, Pamphlets, and Politics in he Dutch Golden Age; Amsterdam University Press: Amsterdam, The Netherlands, 2018.

31. Van 't Hof, T. Enigmatic Etchings. True Religion in Romeyn de Hooghe's Hieroglyphica. Ph.D. Thesis, Utrecht University, Utrecht, The Netherlands, 2019.

32. Daudeij, F. Romeyn de Hooghe (1645-1708) op de Bres voor de Burgerlijke Eenheid. Het Politiek-Religieuze Debat Rond 1700 aan de Hand van de Spiegel van Staat (1706/07). Ph.D. Thesis, Erasmus University Rotterdam, Rotterdam, The Netherlands, 2020.

33. Spaans, J. Graphic Satire and Religious Change. The Dutch Republic 1676-1704; Brill: Leiden, The Netherlands, 2010.

34. Cocceius, J. Summa Doctrinae de Foedere et Testamento Dei; Widow of Johannes and Abraham van Someren: Amsterdam, The Netherlands, 1691.

35. Scriptural Authority and Biblical Criticism in the Dutch Golden Age. God's Word Questioned; van Miert, D., Nellen, H., Steenbakkers, P., Touber, J., Eds.; Oxford University Press: Oxford, UK, 2017. 